\title{
A NEW GENUS AND SPECIES OF THE FAMILY TACHINIDAE, PARASITIC ON ARCHIPS CERASIVORANA.
}

BY CHARLES W. JOHNSON, BOSTON, MASS.

\section{Dichaetoneura n. gen.}

This genus is closely related to Phytomyptera Róndani (Nouvi Annali delle Scienze Naturali di Bologna, 1845, p. 13, Tav. 1, figs. 1, 2). Róndani's figure shows the costal setæ only to the tip of the auxiliary vein, in this genus they are equally prominent to the tip of the first, and nearly as marked to the tip of the second longitudinal vein, one or two more conspicuous setæ are present before the junction of the auxiliary vein. The first longitudinal vein is armed with a large bristle towards the outer end, while the third has two, on the noticeably thickened portion at the base. In other respects it seems to resemble Phytomyptera, i. e.- in having the broad third antennal joint, and in the absence of the apical and posterior transverse veins. The marginal macrochaetae on the second and third abdominal segments are small, there are also discal macrochaetae on the third segment. The latter are sometimes present in Phytomyptera according to Braner and Bergenstamm, (Zweiflügler der Kaiserlichen museums zu Wien, Pt. III, pp. 148, 150, 1893.). Macrochaetae on the fourth segment large and numerous.

\section{Dichaetoneura leucoptera $n$. $\mathrm{sp}$.}

o Head broad, face, front and occiput bluish-gray pollinose, frontal stripe reddish brown, forked above and narrowly extending along the ocellar triangle, upper angle of the checks also reddish brown, facial depression deep, and ridge prominent; vibrissae large with numerous smaller bristles above and on the cheeks, frontal bristles descend to nearly opposite the second antennal joint, there are two pair of orbital bristles, and the ocellar bristles are directed forward; first and second joints of the antennae, brown, very short, the second setose, the third black, broad and obtusely truncate, arista black, palpi brown.

Thorax including the pleurae and scutellum bluish gray pollinose, with two short, black, anterior, dorsal lines, and four postsutural and four sternopleural macrochaetae; scutellum bearing four pairs of marginal macrochaetae, two smaller bristles 
are also present on the disc of the scutellum. Abdomen broad, entirely black, somewhat shining and covered with fine setae. Legs black, with prominent rows of bristles. Wings broad with a whitish or milky tinge, costa and first longitudinal vein dark brown, the other veins yellowish. Squamae white. Length, $5 \mathrm{~mm}$.

Five specimens of this species were obtained from Dr. F. W. Russell of Winchendon, Mass., who bred them from the pupa of Archips cerasivorana Fitch. Later I received a specimen from Mr. E. F. Hitchings of Waterville, Me., who bred it from the same moth, July 28, 1906. Mr. D. W. Coquillett informs me that the National Museum has also received a specimen from Mr. Hitchings. Type in the collection of the Boston Society of Natural History.

In connection with this I should also like to record the host of Actia pilipennis Fallen, which was bred from Schizura concinna S. \& A., August 13, 1905, by Prof. John Barlow, of Kingston, R. I.

Entomological Society of America.-The initial meeting was held in the American Museum of Natural History at New York City, Dec. 28, 1906. Prof. Wm. M. Wheeler delivered before the society an illustrated lecture on "The Polymorphism of Insects." Immediately after the lecture occurred the business meeting. Prof. J. H. Comstock of Ithaca, N. Y., was elected chairman and E. S. G. Titus of Washington, D. C., secretary of the meeting. The new society then adopted a constitution and by-laws and elected officers and the other members of the executive committee.

The following are the officers: President, J. H. Comstock, Ithaca, N. Y., 1st Vice President, James Fletcher, Ottawa, Can., 2nd Vice President, Henry Skinner, Philadelphia, Pa., Sec.-Treasurer, J. Chester Bradley, Berkeley, Cal.

The Executive Committee consists of the officers and the following Fellows: Wm. M. Wheeler, New York, N. Y., John B. Smith, New Brunswick, N. J., Herbert Osborn, Columbus, O., C. J. S. Bethune, Guelph, Can., F. M. Webster, Washington, D. C., and Chas. W. Johnson, Boston, Mass.

Following the business meeting there was a smoker at the Hotel Endicott given by the Brooklyn, Newark and New York Entomological Societies to the Association of Economic Entomologists and the Entomological Society of America.

The executive committee, at a meeting held December 29, decided to call a meeting of the society.at Boston, Mass., in connection with the meeting of the International Zoological Congress in August, 1907. Full announcement will be made later. E. S. G. Tirus, Secretary. 

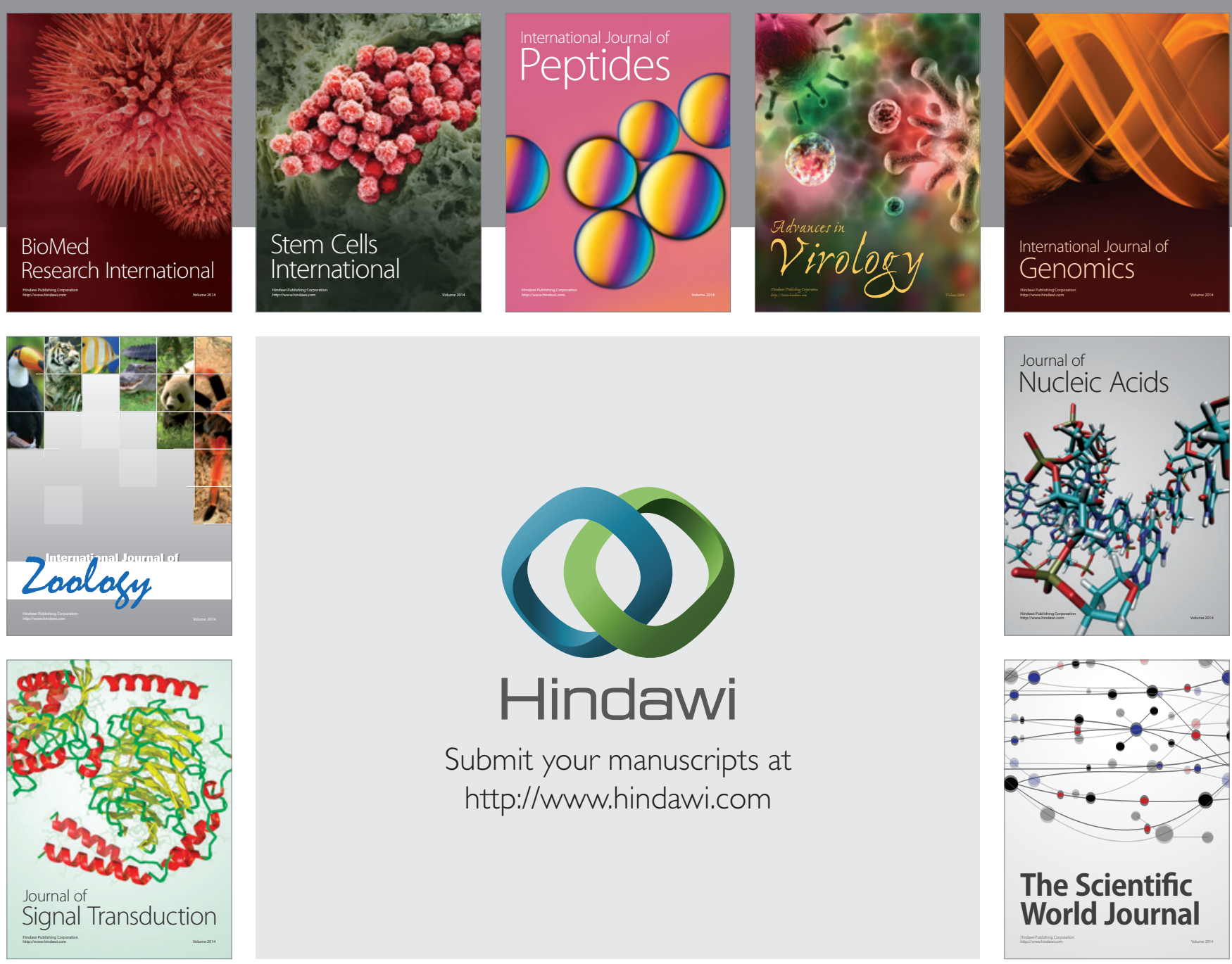

Submit your manuscripts at

http://www.hindawi.com
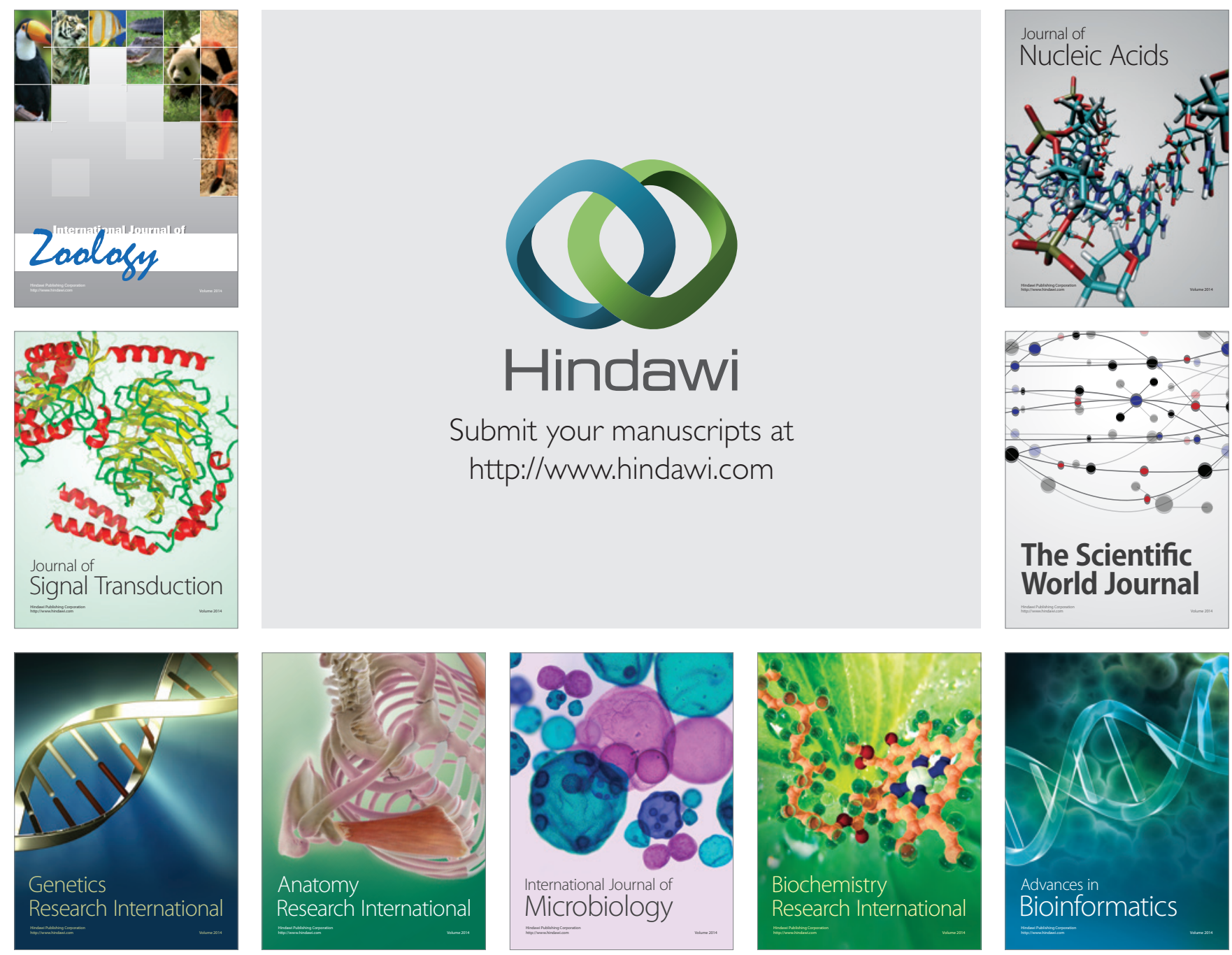

The Scientific World Journal
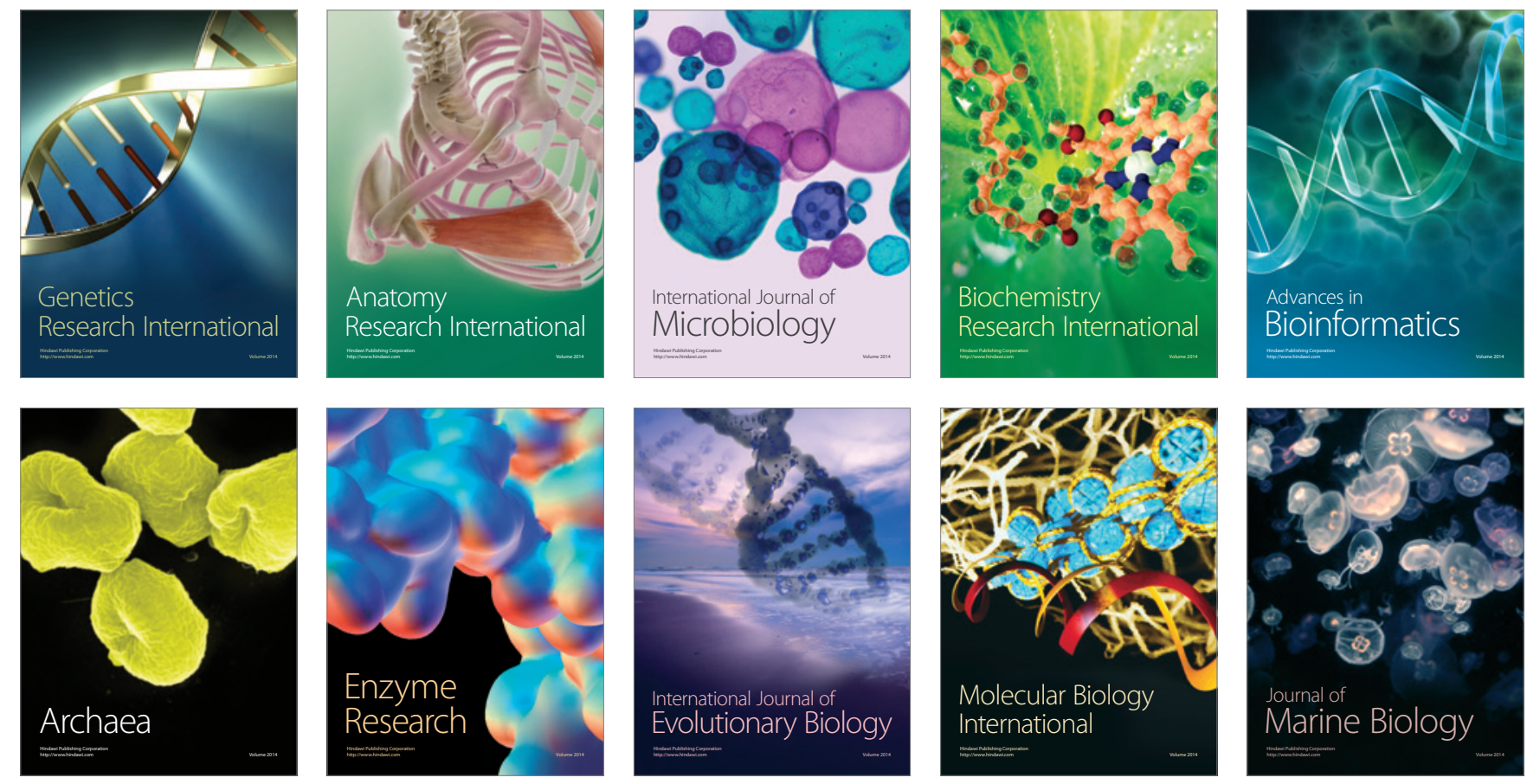